avidence from the progeny of partially sterile interand intra-specific hybrids in A pocynum, Galeopsis, and Oryza indicates that there is no direct genetic connexion between the causal agents of hybrid sterility and the genes. which produce the visible differences between species. This association in Nature is a result of parallel evolution.

Based upon these five assumptions, a working hypothesis is formulated to explain the relationship in evolution between morphological divergence, or descent with modification, and the development of discontinuities in the variation pattern of natural groups of organisms, or the origin of species. Descent with modification takes place as a result of the interaction between mutation, natural selection, and the random fixation of genes in small populations. If these forces are relatively static, the species will not evolve. Discontinuities are developed when two parts of a more or less rapidly evolving species are separated from each other by any of a number of isolating mechanisms. These mechanisms evolve gradually, and are genetically independent of the changes in outward form which produce visibly different species.

\section{TERMITE-PROOFING OF TIMBER}

$\mathrm{T}$ ERMITES, or 'white ants' in popular terminology, are known to most of the inhabitants of the tropical parts of the world, and also to some warm temperate regions such as parts of the United States. Although occasionally introduced into Great Britain, they have never made any headway in this temperate island climate. Various remedies or preventions against the termites' attacks have been introduced or are practised locally in tropical countries-some effective, or partially effective, others more or less worthless. One of the greatest troubles and losses from this pest is the depredations it commits on furniture, instrument boxes, packing cases, etc., made in Britain (or in temperate Europe generally) and sent to the tropics; in termiteinfested areas such have little chance of escaping destruction.

There is an exception--teak is unattacked, and so articles made from teak are immune. The writer had a full-plate expensive camera in India packed in a beautifully built teak wood box. It was left on the cement floor in a corner of a room in a well-built rest house out in the District. Returning three weeks later an inspection of the box showed traces of termites round the bottom edges. The box was unlocked and lid opened. The wood work of the camera, mahogany, was entirely eaten, skeleton 'beams' and cross pieces being left to support tine brass mountings of the camera. At a touch the whole structure collapsed. An examination showed that the bottom of this expensive teak brass-cornered box had consisted of a piece of pine wood.

Leaflet No. 38 (Forest Prod. Res. Lab., Princes Risborough, Department of Scientific and Industrial Research; Aug. 1944) is entitled "Termite-Proofing of Timber for Use in the Tropics". This leaflet opens with the statement that manufacturers in Great Britain handling timber, or making furniture, etc., for use in the tropics are often called upon to render wood proof against possible infestation by the termites, and therefore are directly concerned in the injury which these insects may cause. It is admitted that in some countries termites cause the most serious damage, especially to permanent structures, unless precautions have been taken during their planning and construction. "In temporary structures and contents of buildings the risk of severe damage, it is said, is less and it need not be assumed that all materials or articles in which wood is present will at once be attacked and rapidly destroyed by termites when brought into a country in which these insects occur". There may be an element of truth in this, but the experience of many must render them chary of subscribing to this statement, or of taking the risk. Temporary structures may be ruined in a few days if left uninspected.

The leaflet summarizes information from a number of publications from certain countries, particularly from those of the Forest Research Institute, Dehra Dun, and the Bureau of Entomology, United States Department of Agriculture, and gives a brief account of how termite damage takes place; and also how it may be prevented. The subject is treated under the headings : habits of termites, prevention of damage, use of timber treated with wood preservatives, use of termite-resistant woods (among those usually available in Great Britain are iroko (Chlorophera excelsa), opepe (Sarcocephalus diderrichii), Pacific Coast redwood (Sequoia sempervirens), teak (Tectona grandis)). Plywood and fibre or composition boards and termite attack are also dealt with. It is said that treatment against termites will in most cases also prevent destruction of timber through fungal decay,

\section{MAGNESIUM DEFICIENCY OF FRUIT TREES}

$T$

$\mathrm{HE}$ occurrence of magnesium deficiency of fruit trees growing in the field has been recognized only in recent years. L. Southwick (Proc. Amer. Soc. Hort. Sci., 42, 85 ; 1943) describes a leaf blotch of apples which appears as an edge burn or interveinal necrosis, together with in some varieties a yellow banding or mottling of the leaves, appearing first in the older leaves and associated with a low mag. nesium content of the leaves, the scorched leaves usually containing less than $0 \cdot 25$ per cent magnesium. In the same journal D. Boynton, J. C. Cain and O. C. Compton report that seasonal variations in the potash and magnesium content of apple leaves agree with the seasonal differences in the incidence of leaf scorch and leaf blotch respectively. Leaf blotch due to magnesium deficiency may be reduced by soil application of magnesium sulphate, while it is aggravated by chloride of potash dressings (ibid., 42, 95 ; 1943). L. Southwick and J. K. Shaw find that spraying with magnesium sulphate solution (16 lb. per 100 gallon) gave a partial control of the magnesium deficiency leaf blotch, and that most magnesium-containing substances applied to the soil were effective but magnesium limestone was ineffective in curing the trouble.

In the tung (Aleurites fordii) magnesium deficiency symptoms again consist of leaf blotches which increase in size at the margin and the development of brown necrotic areas which progress from the margin inwards between the main veins. As with apples, magnesium sulphate as a soil dressing effects a cure, but soil applications of potash aggravate the symp. toms (M. Drosdoff and A. L. Kenworthy, ibid., 44, 1 ; 1944). 